\title{
Field Key to Identification of Scale Insects on Holly (Ilex spp. $)^{1}$
}

Jamba Gyeltshen and Amanda C. Hodges ${ }^{2}$

Over 500 different varieties of hollies (Ilex spp) are grown in the US as hedges, garden borders, and specimen plants. A well managed planting is generally free of pests and diseases but when growing conditions are poor, pest and disease can become a problem (Ingram and Barrick 2003). Clemson Extension website provides an overview of the pest and disease problems on hollies.

Scale insects commonly occur on woody ornamentals where they infest twigs, branches, leaves, fruits, and damage them by feeding on the phloem with their piercing/sucking mouthparts. Damage symptoms include chlorosis or yellowing, premature leaf drop, restricted growth, branch dieback, and even plant death. When scale insects excrete honey-dew, the foliage gets covered with sooty mold (Figure 1).

Hollies are infested by many types of scales. The two major types include armored scales (Family: Diaspididae) and soft scales (Family: Coccidae). About 50 per cent of the known 350 armored scale species and 70 percent of the known 85 soft scale species in the United States are found in Florida (Short and Castner 2003).

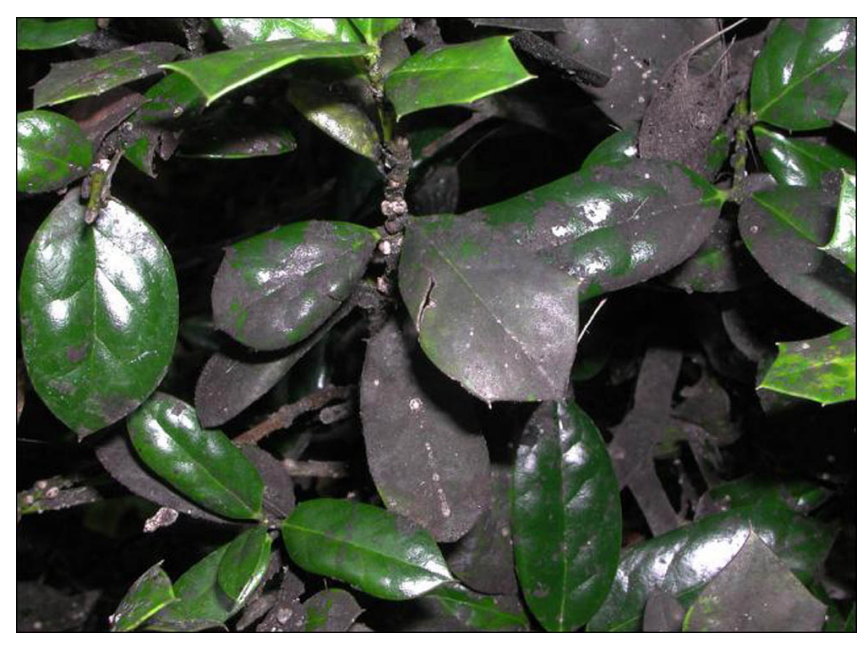

Figure 1. Sooty mold on holly resulting from Florida wax scale infestation. Credits: R.J. Gill, California Department of Food and Agriculture (CDFA)

The adult female of the armored scale produces a waxy secretion to form a protective cover that resembles a plate of armor. But the protective cover is not an integral part of the insect body. In contrast, the waxy secretion of soft scale is an integral, inseparable portion of the body. There are other subtle differences between the two groups (Table 1).

1. This document is IPM-141 (IN649), one of a series of the Entomology and Nematology Department, Florida Cooperative Extension Service, Institute of Food and Agricultural Sciences, University of Florida. First published: January 2006. Please visit the EDIS Website at http://edis.ifas.ufl.edu.

2. Jamba Gyeltshen, DPM graduate student, and Amanda C. Hodges, SPDN assistant director in entomology and training/education, Cooperative Extension Service, Institute of Food and Agricultural Sciences, University of Florida, Gainesville, FL 32611.

The Institute of Food and Agricultural Sciences (IFAS) is an Equal Opportunity Institution authorized to provide research, educational information and other services only to individuals and institutions that function with non-discrimination with respect to race, creed, color, religion, age, disability, sex, sexual orientation, marital status, national origin, political opinions or affiliations. U.S. Department of Agriculture, Cooperative Extension Service, University of Florida, IFAS, Florida A. \& M. University Cooperative Extension Program, and Boards of County Commissioners Cooperating. Larry Arrington, Dean 


\section{Life Cycle}

The life cycle of scale insects vary among species. The following descriptions provide a generalized background of scale insect biology. A basic understanding of the pest biology is helpful for utilization of field keys.

Scale insects are known to have diversity of reproductive systems including hermaphroditism (bisexuality) and parthenogenesis (Ben-Dov et al. 2001). Adult females lay eggs or give birth to live young (first instar). Eggs are either laid in a cavity under the female body or in a waxy cover attached to the body. The scales that are newly born or hatched are known as crawlers. In this stage it moves about in search of succulent new growth to feed upon.

Female undergoes simple metamorphosis with three to four total instars and does not have a pupa-like instar, whereas male undergoes complete metamorphosis with 5 instars including two pupa-like instars. During the pupa-like instars male has only rudimentary mouthparts and does not feed (Ben-Dov et al. 2001). The adult female scales, however, feed continuously and remain fixed in one location or have very limited movement.

\section{Description}

Adult: Adult females of armored and soft scales are sessile, legless, wingless, and do not have a clear head and body region. The body form and shape varies from being circular, oval, hemispherical, oblong, thread-like to being pear-shaped. The most characteristic feature of the scale insects is that they secrete copious amounts of wax-like secretion. In the armored scales, the waxy secretion together with their cast skin forms a hard and protective coating. In the soft scales, however, there is no true armor but their body is still hardened by a waxy secretion.

Male scales are more insect-like in appearance with a distinct head, thorax, an abdomen region and wings. The adult male lives for a day or less and never feeds (Ben-Dov et al. 2001).

Egg: Eggs are laid underneath the waxy covering and remain there for one to three weeks before they hatch. If an adult female is turned over, it is possible to see the egg mass as shown in Figure 2.

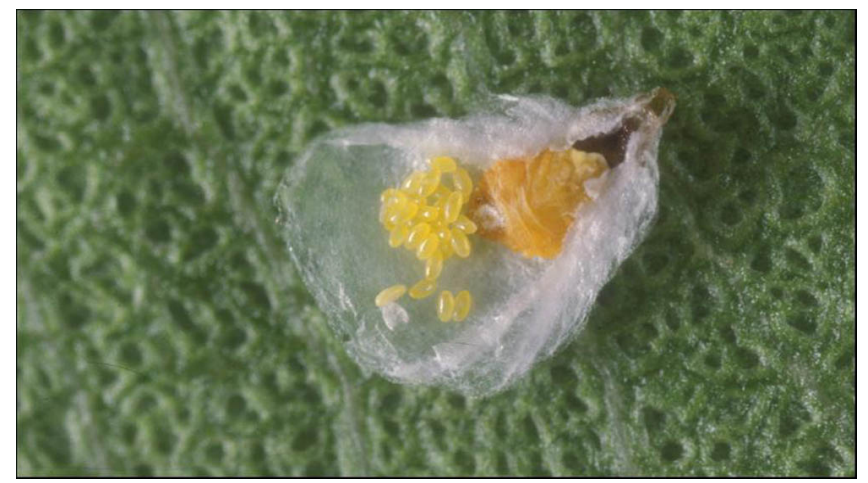

Figure 2. False oleander scale female, turned over to show eggs and female body. Credits: Lyle Buss, University of Florida

Immature stages: The crawlers or the first instar have well developed legs and are capable of active movement in search of suitable feeding sites. Usually both sexes look alike during the first instar but when they molt to a second instar, sexual dimorphism is apparent. Sexual dimorphism may occur for some armored scale species in the first instar. Female scales are oval to circular in shape and without dorsal tubular ducts, whereas males are elongate oval and possess the dorsal tubular ducts (Hamon and Williams 1984). Females have 2 to 3 immature stages without any pupa-like instars while males have 4 immature stages with the two pupa-like instars.

\section{Management}

Natural controls (parasitoids, predators, pathogens, environmental conditions) usually maintain scale populations below damaging levels and chemical control is often unnecessary even under tree crop situations such as citrus which is host to many scale insects (Futch et al. 2001). If one observes many pin-sized holes on the body of scales, it is a sign of natural control provided by parasitic wasps. The pinholes are exit holes of adult parasitic flies. However under situations where natural control is inadequate, integrated pest management (IPM) practices are recommended. IPM includes operations aimed at maintaining the plant vigor through proper water and nutrient management, and integrating all other possible control tactics to manage the problem instead of emphasizing just on chemical control. However, under circumstances when scale insect population builds up to damaging levels, chemical treatments may be necessary. Timing of spraying operation is crucial as scales are difficult to control 
Table 1. Difference between armored scale and soft scale.

\begin{tabular}{||l|l|l||}
\hline \multicolumn{1}{|c|}{ Features } & \multicolumn{1}{|c|}{ Armored Scale } & \multicolumn{1}{c|}{ Soft Scale } \\
\hline Protective coating & Hard and armor-like & $\begin{array}{l}\text { No true armor; skin or body hardened by } \\
\text { wax-like secretion }\end{array}$ \\
\hline Protective cover & $\begin{array}{l}\text { Not integral part of the body; it can be } \\
\text { separated from the body }\end{array}$ & $\begin{array}{l}\text { Integral part of the body; cannot be } \\
\text { removed }\end{array}$ \\
\hline Length of piercing mouthpart & Long & Short \\
\hline Feeding & $\begin{array}{l}\text { Females remain permanently fastened to } \\
\text { the plant part }\end{array}$ & $\begin{array}{l}\text { Females not fastened permanently until } \\
\text { they are ready to lay eggs }\end{array}$ \\
\hline $\begin{array}{l}\text { Honey dew excretion } \\
\text { death }\end{array}$ & Do not excrete honey dew & Excrete honey dew \\
\hline \hline
\end{tabular}

with contact insecticides because they are well protected by their armor or waxy cover. Spraying should be carried out before young crawlers develop their cover and are still vulnerable.

For specific information on products labeled for scale insects in the state of Florida, a range of products have been listed by Buss and Turner (2004).

\section{Field Key}

The general descriptions of the scale insects in the following key is largely based on Hamon and Williams (1984) and Dekle (1976).

1.a. Insect body protected by tough cover or armor (oysterlike) that can be lifted and removed--------------------------------------------------10

b. Tough armor lacking; no oysterlike cover or removable hard cover---------- 2

2.a. Insect body covered with thick grey to pinkish white wax----Wax scales (3)

b. Insect body not covered by thick whitish wax----------------------------------5

3.a. Body divided into plates or appear platelike; one dorsal plate and 6 lateral plates with nuclei; rectangular to oval in dorsal view; beige to grayish white 2 to $5 \mathrm{~mm}$ ( $\sim 0.1$ to 0.2 inch) long; wax horns absent.------------------Barnacle scale (Figure 3)

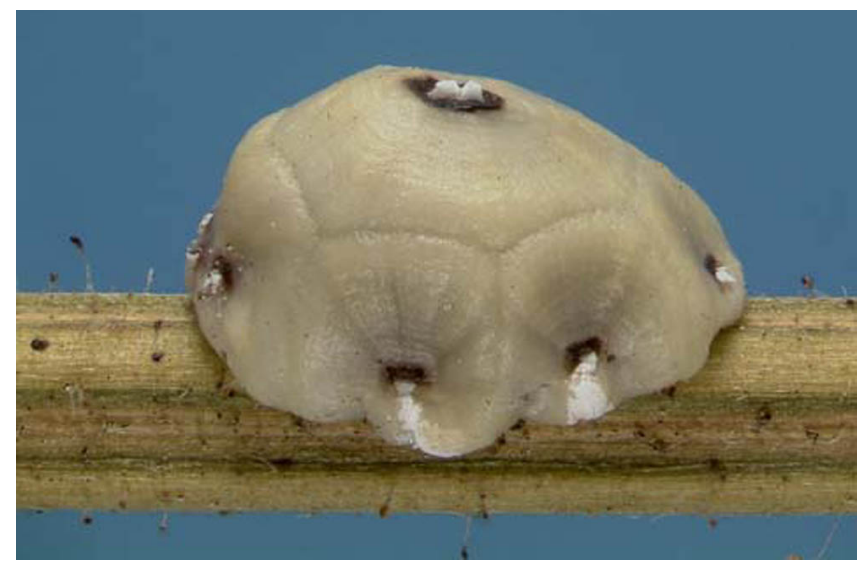

Figure 3. Barnacle scale (Ceroplastes cirripediformis). Credits: Dr. Avas Hamon and Jeff Lotz, FDACS-DPI

b. Body not divided into plates; wax horns may or may not be present-------4

4.a. Body oval in dorsal view, nearly flat in young females and hemispherical in older one; body plates and nuclei not apparent; color is white to pinkish white which becomes dirty white with age; 2 to $4 \mathrm{~mm}(\sim 0.1$ to $0.2 \mathrm{inch})$ in length--Florida wax scale (Ceroplastes floridensis) (Figure 4)

b. Body convex, circular or irregular in outline, and covered with thick white or pinkish white wax; normally with an anteriorly projecting horn---Indian wax scale (Figure 5)

5. a. Body oval or slightly elongate to oval, strongly convex or hemispherical; nymphs with pinkish coloration and $\mathrm{H}$-shaped ridges----------Hemispherical scale (Figure 6) 


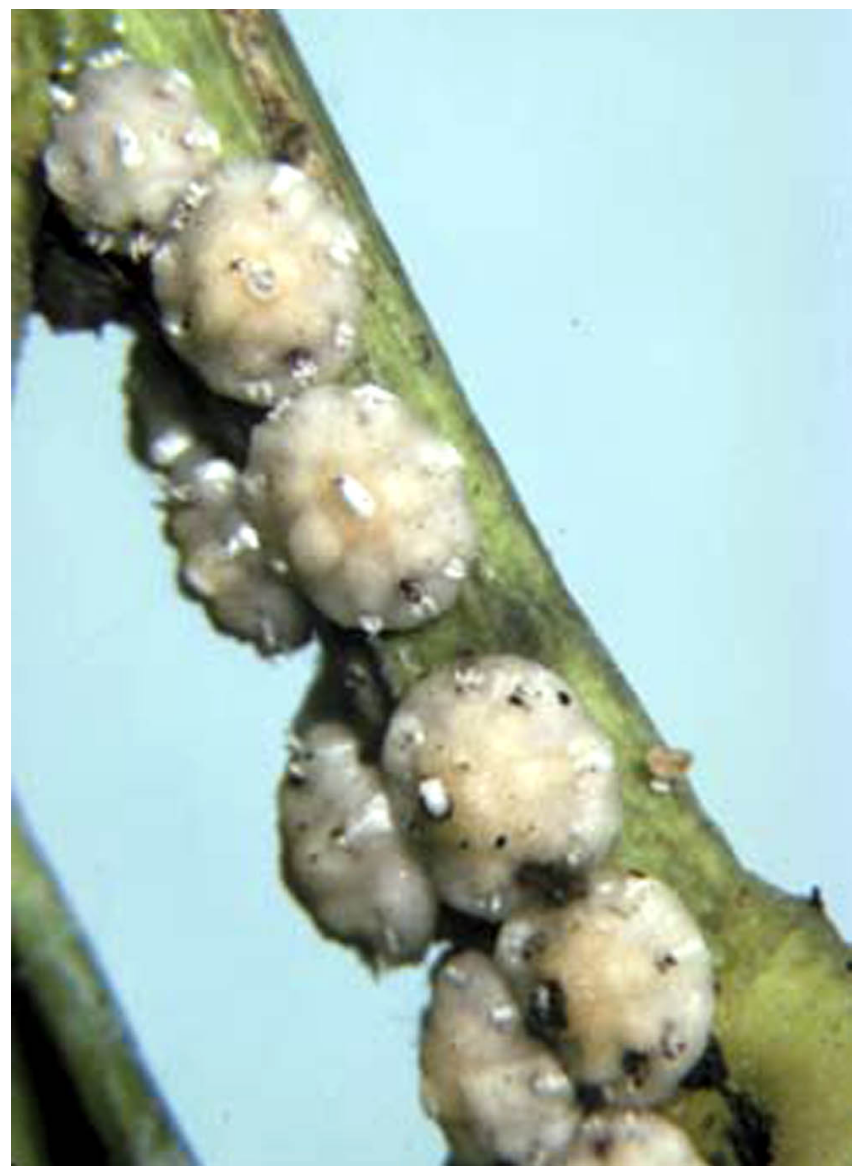

Figure 4. Florida wax scale (Ceroplastes floridensis). Credits: R.J. Gill, CDFA

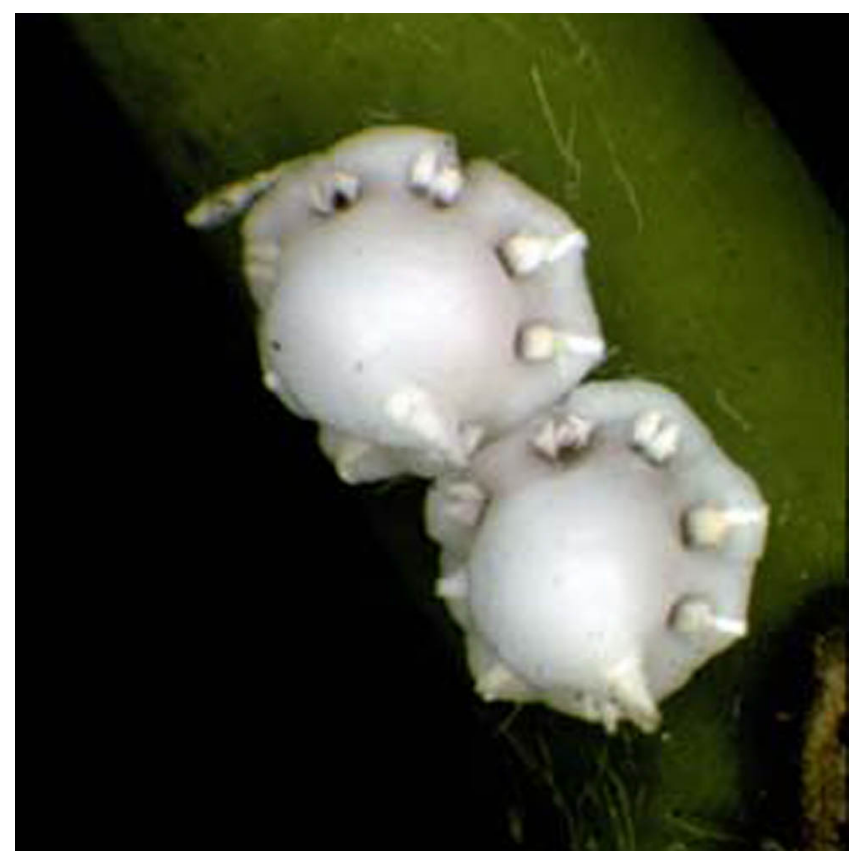

Figure 5. Indian wax scale (Ceroplastes ceriferus). Credits: M.B. Stoetzel, USDA-ARS

b. Body not strongly convex or hemispherical
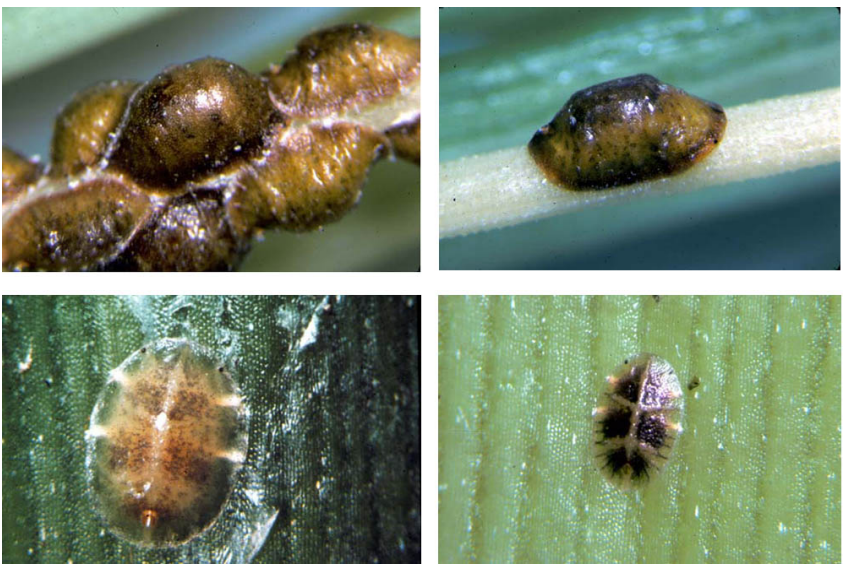

Figure 6. Hemispherical scale (Saissetia coffeae). Credits: R.J. Gill, CDFA

6.a. Body oval and flat; pale yellowish-green to yellowish brown, often mottled with brown spots or with brown stippling, 2.5 to $4 \mathrm{~mm}(\sim 0.1$ to 0.2 inch) long------Brown soft scale (Figure 7)
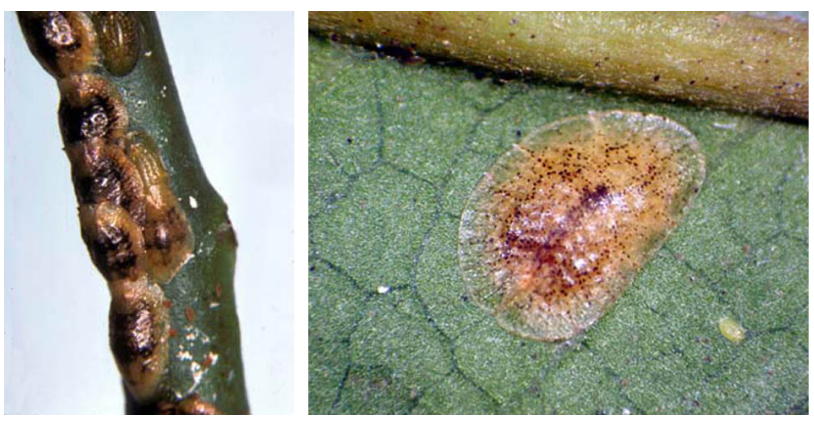

Figure 7. Brown soft scale (Coccus hesperidium). Credits: R.J. Gill (left); Dr. Avias Hamon and Jeff Lotz, FDACS-DPI (right)

b. Body oval to roughly triangular in shape, almost flat or only slightly convex --7

7. a. Female body triangular (irregular), flat and thin in profile with front angle bluntly pointed; pale to yellowish green----------------Acuminate scale (Figure 8)

b. Body slightly flat and convex, not triangular as above $-8$

8.a. Adult female oval, opaque, reddish brown to dark brown, and 4 to $5 \mathrm{~mm}$ ( 0.2 inch) in length; dorsal surface with reticulate pattern and sclerotized Tessellated scale (Figure 9)

b. Body description different from above $--9$ 


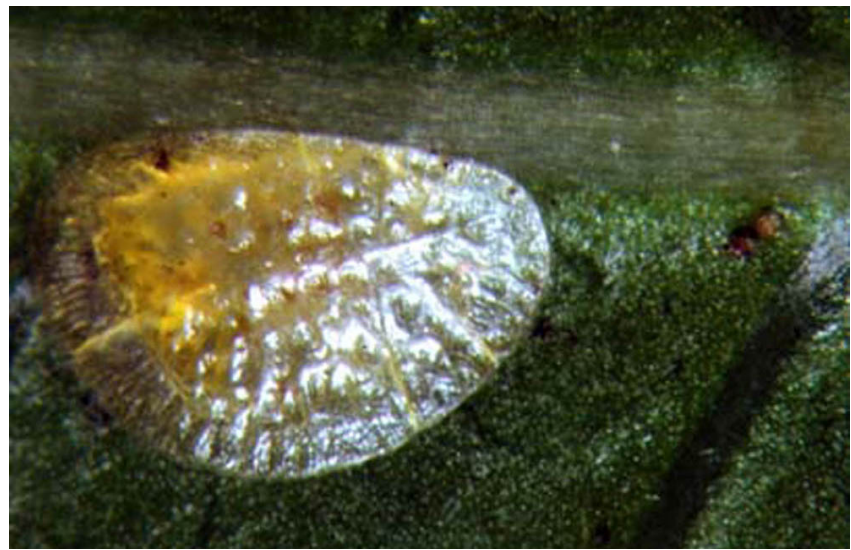

Figure 8. Acuminate scale (Kilifia acuminata). Credits: Paul M. Choate, University of Florida

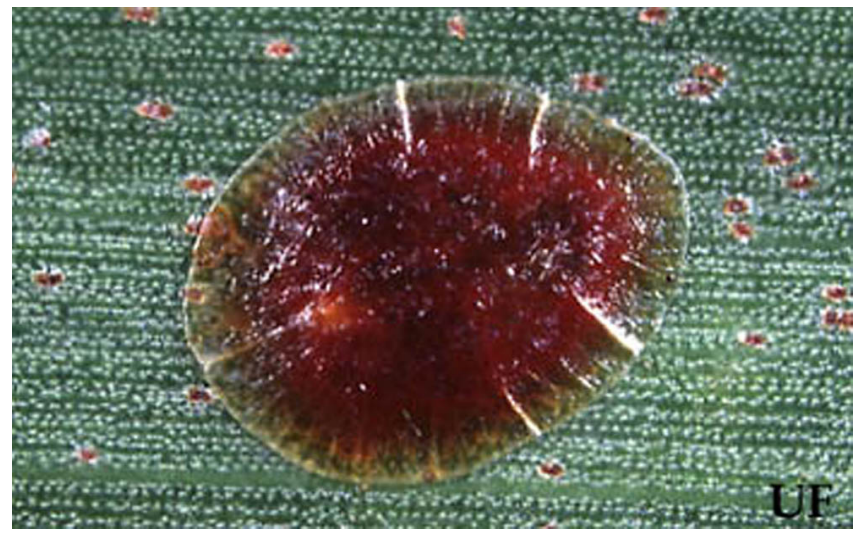

Figure 9. Tessellated scale (Eucalymnatus tessellates). Credits: Paul M. Choate, University of Florida

9. a. Possess a glassy wax covering with conspicuous median longitudinal ridge, radiating striations as well as concentric striations-------Glass scale (Figure 10)

b. Body elongate-oval, 2-3 mm ( 0.1 inch) long, pale to dark brown, and soft. Females most conspicuous with $6 \mathrm{~mm}$ (0.2 inch) long, cottony white egg sacs protruding from the rear--------Cottony camellia scale (Figure 11)

10.a. Body broadly or narrowly elongate----------------------------11

b. Body oval to circular in shape $-13$

11. a. Body broadly elongate; adult females 2-3 $\mathrm{mm}$ (0.1 inch) long, with pyriform snow-white cover; body yellowish brown---------------False oleander scale (Figure 12)

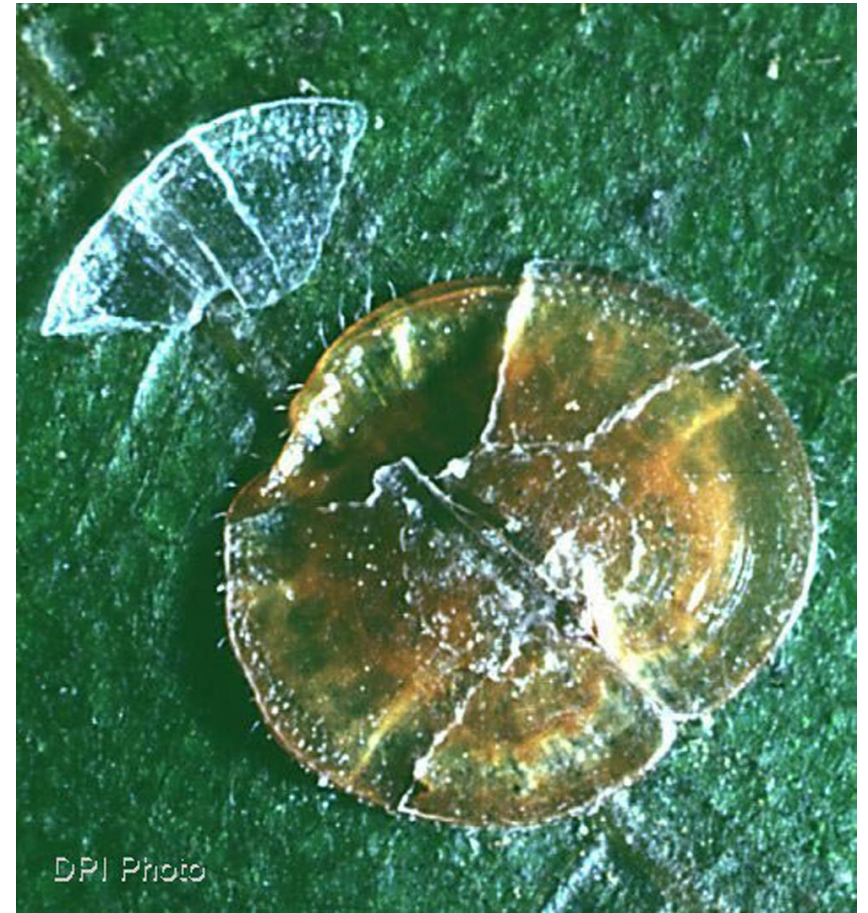

Figure 10. Glass scale (Inglisia vitrea). Credits: DPI, FDACS, Florida

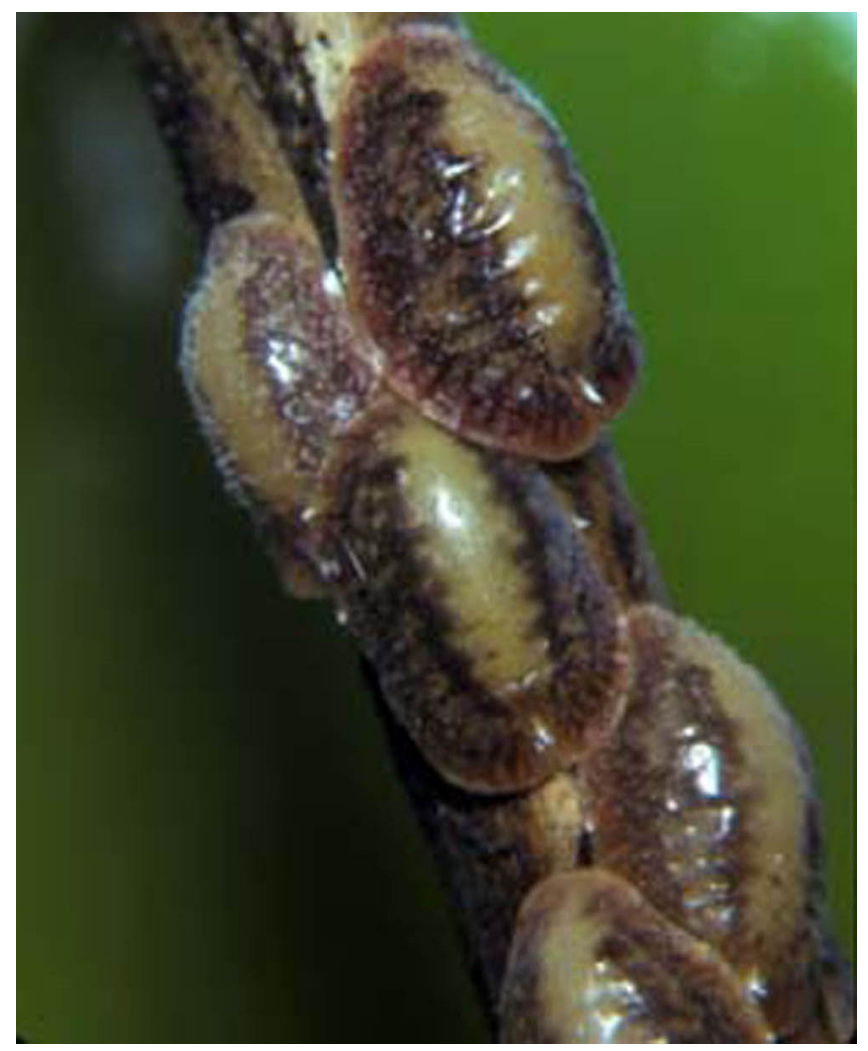

Figure 11. Cottony camellia scale (Pulvinaria floccifera). Credits: R. J. Gill, CDFA

b. Body narrowly elongate, oyster-like12 


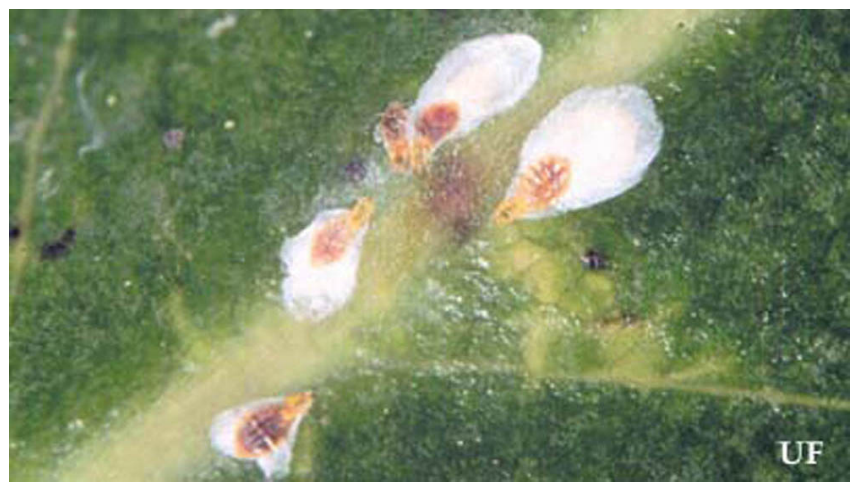

Figure 12. False oleander scale (Pseudaulacaspis cockerelli). Credits: University of Florida

12.a. Grayish or blackish brown with lighter margins; male (seen as white) elongate, slender, sides parallel, with conspicuous longitudinal ridge---------Euonymus scale (Figure 13)

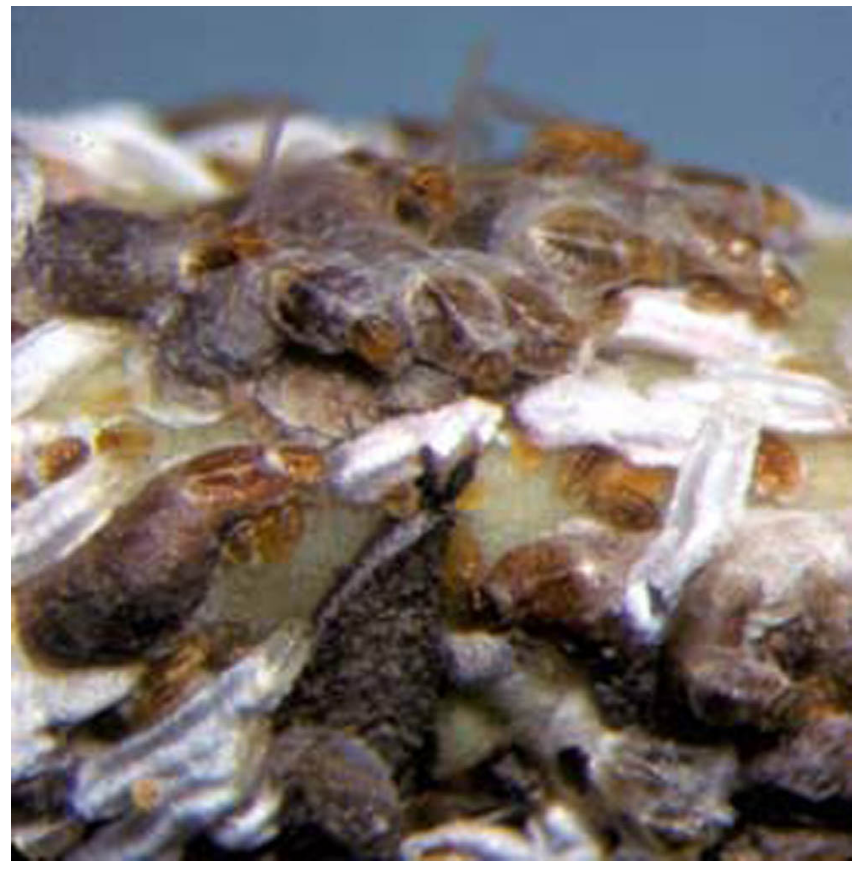

Figure 13. Euonymus scale (Unaspis euonymi). Credits: R.J. Gill, CFDA

b. Body elongate, adult female 1-2mm ( $\sim 0.1$ inch) in diameter, purple to dark brown, ----Purple scale (Figure 14)

c. Adult female dark brown to gray or almost black; size $1.5 \mathrm{~mm}$ with a median ridge running along midline of body-----------Tea scale (Figure 15)

13.a. Armor appearing circular; armor reddish brown --------------------14

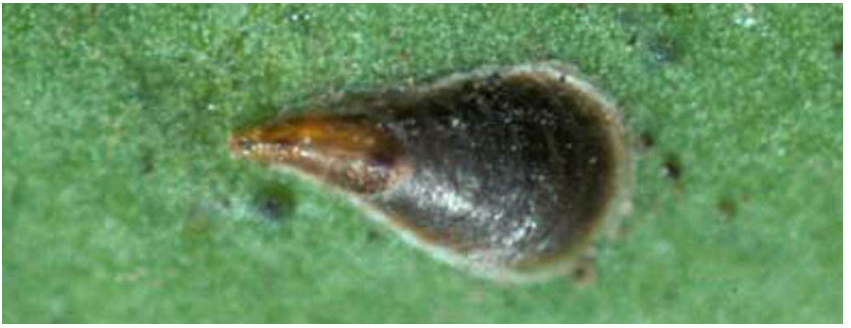

Figure 14. Purple scale (Lepidosaphes beckii). Credits: D.R. Miller, USDA-ARS

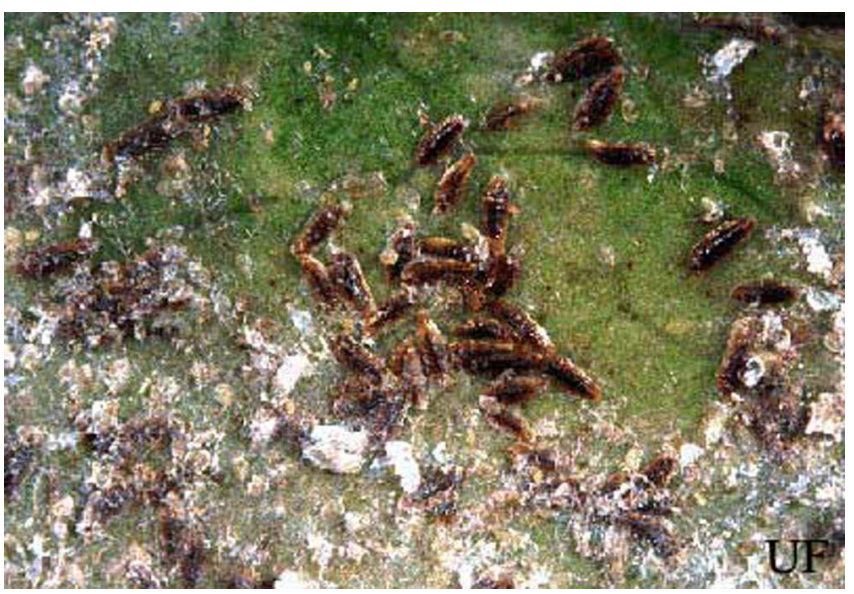

Figure 15. Tea scale (Fiornia theae). Credits: University of Florida

b. Armor irregular shaped; appearing tan to offwhite15

14. a. Moderately convex; cover with three concentric rings; appear red to coppery at margin -Florida Red Scale (Figure 16)

b. Slightly convex; cover with three concentric rings; light fringe-----California Red Scale (Figure 17)

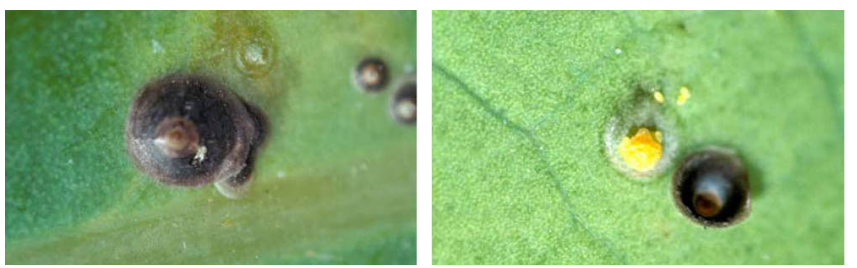

Figure 16. Florida red scale (Chrysomaphalus aonidium) Left: with intact armor (exuvia); Right: armor removed. Credits: D.R. Miller, USDA-ARS

15. a. Strongly convex, usually dirty white circular cover, tan to white, with yellow central exuvium; body yellow; adult female 1-2 mm ( 0.1 inch) in diameter ------Latania scale (Figure 18)

b. Adult female circular to oval, flat to slightly convex; flat forms are transparent white, and convex 


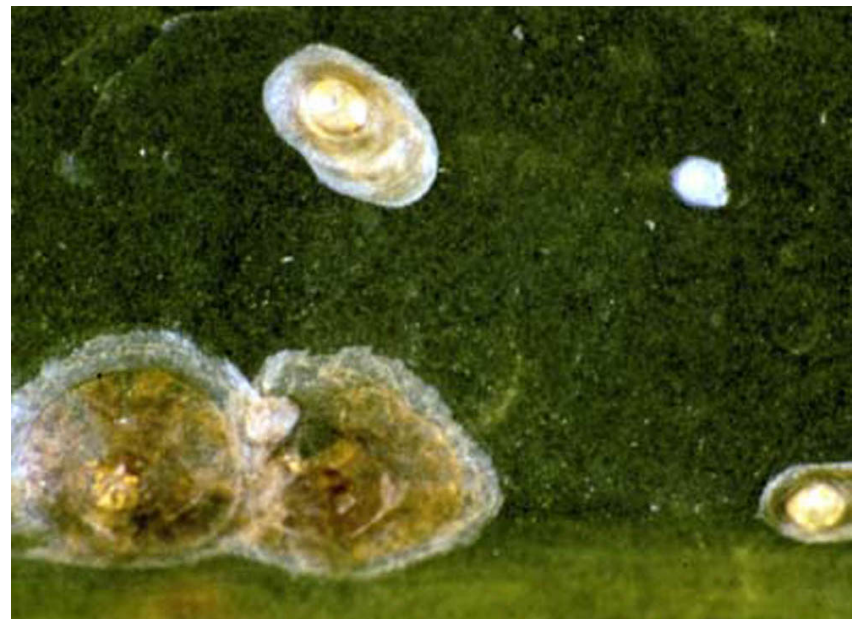

Figure 17. California red scale (Aonidiella aurantii). Credits: J. Davidson, University of Maryland

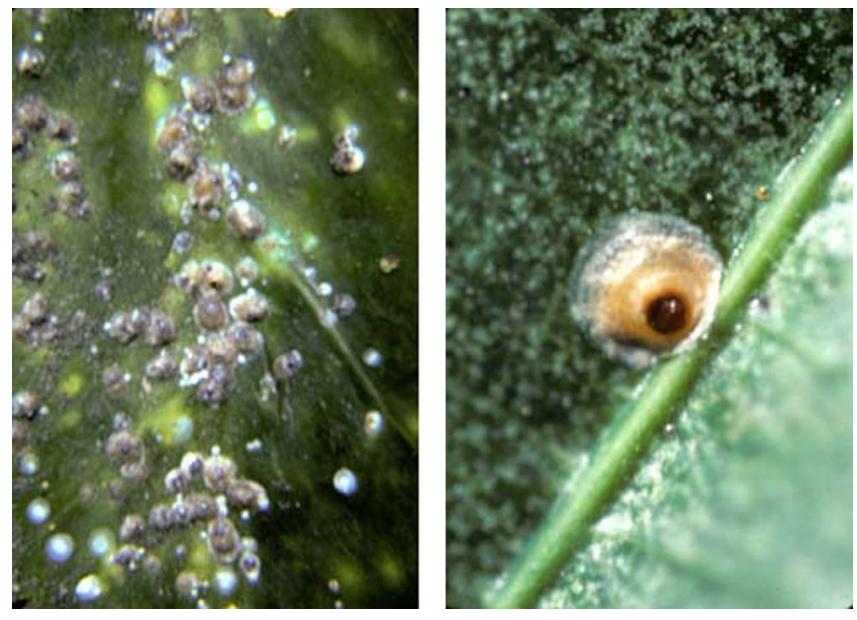

Figure 18. Lantania scale (Hemiberlesia lataniae). Credits: R.J. Gill, CFDA (left); D.R. Miller, USDA-ARS (right)

forms are light brown Oleander scale (Figure 19)

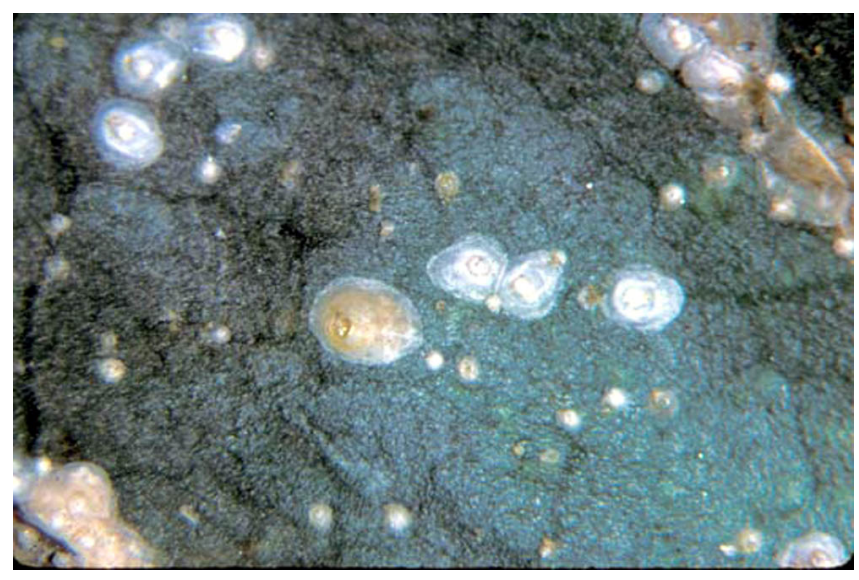

Figure 19. Oleander scale (Aspidiotus nerii). Credits: R.J. Gill, CFDA

\section{References}

Ben-Dov Y, Miller DR, Gibson GAP. 2001. ScaleNet (Scale Insects-General information). http://www.sel.barc.usda.gov/scalenet/scalenet.htm (21 December, 2005)

Buss EA, Turner JC. 2004. Scale Insects and Mealybugs on Ornamental Plants. EDIS. University of Florida. http://edis.ifas.ufl.edu/MG005 (21 December, 2005)

Dekle GW. 1976. Florida Armored Scale Insects. Florida Department of Agricultural and Consumer Services, Division of Plant Industry. Arthropods of Florida and neighboring land areas 3: 1-345.

Futch SH, McCoy CW, Childers CC. 2001. A Guide to Scale Insect Identification. EDIS, University of Florida. (December 20, 2005)

Hamon AB, Williams ML. 1984. Florida Department of Agricultural and Consumer Services, Division of Plant Industry. Arthropods of Florida and neighboring land areas Vol. 2.

Ingram DL, Barrick WE. 2003. Hollies of Florida. University of Florida EDIS http://edis.ifas.ufl.edu/MG021 (November 18, 2005).

Miller GL, Miller DR, Limones EM, Gill RJ, Carlson RW. 2005. The United States National Collection of Scale Insect Photographs. ScaleNet. (19 December, 2005).

Short DE and Castner JL. 2003. Scale Insects Affecting Ornamental Plants. EDIS. University of Florida. (21 December, 2005). 